\title{
An evaluation of the Effect of the Elements of the Resource-Based approach on the Expert Performance based on the focus Competitive Strategy in Non-Metal Mineral Industry
}

\author{
Kiumars Sharifi \\ Ph.D., Faculty of Management, Tehran University, Tehran, Iran
}

Abdolhossein Karampour
Ph.D., Faculty of Management and Accounting, Shahid Beheshti University, Tehran, Iran

EInaz Rahrovy

(Corresponding Author)

MS c. student in MBA, Faculty of Management, Tehran University, Tehran, Iran

E-mail: Elnaz.Rahrovy@ut.ac.ir

Accepted: December 09, 2012 Published: January 26, 2013

Doi:10.5296/ijld.v3i1.3143 URL: http://dx.doi.org/10.5296/ijld.v3i1.3143

\begin{abstract}
The purpose of the research is to evaluate the effect of the elements of resource-based approach on the expert performance based on the focus competitive strategy in the non-metal mineral industry of the country. For this purpose, the approaches available in the areas determining the export performance were identified that included occasional approach, the approach of business interactions network, and the resource-based approach. In this study, using the resource-based approach, the researcher examines the relations between the elements of the resource-based approach of the organization, the competitive strategies and the performance that are the main components of the research. The research is to find that how the main elements of the resource-based approach lead directly and indirectly (through competitive strategies) to high levels of performance. The conceptual model of the present research combines indeed three main elements in the strategic management, i.e. the internal environment (resources, capabilities and competitive organizational systems), competitive distinction strategy and the export performance. 300 questionnaires were distributed, of which 285 questionnaires could be analyzed. According to the results, the competitive resources have the highest effect (39\%) on the export performance and the focus strategy (63\%).
\end{abstract}

Keywords: Competitive Resources, Competitive Capabilities, Organizational Systems, Focus Competitive Strategy, Export Performance 


\section{Introduction}

The role and the importance of the export in the economic growth and development of the country are evident for every one, and it is one of the most vital economy sectors of any country. An analysis of the status of 41 countries by the World Bank from 1963 to 1985 showed that the economic performance of countries with an external economy have been better than the internal economies almost in every aspect. At the levels of an economic firm, export also plays a positive and useful role. At the levels of an economic firm, export also plays a positive and useful role. At the level of firms, export creates significant opportunities for growth ands development. With the extension of the access to the foreign markets, a company can achieve a higher level of production and efficiency if it produces lower than the nominal rate. This decreases the unit finished price and provides higher rates of profits. The globalization trend also leads to the increase of competition, integration and liberation in the international markets that is a reason for the rise of the importance of product export and the fact that it has become more important for public politicians and the public sector [3]. So for this purpose, in this research, the importance of the export performance is examined. The perspective of the increase in non-petroleum export is offered for many years by the governors. Although governments have always tried to realize this perspective, the comparison of the statistics of non-petroleum export of the country with other countries shows that they have not been very successful and more planning is needed. It indicates that in practice, managers could not identify the factors effective in the export to export better [10]. Iran is one of a few countries that have many valuable mineral resources naturally. For example, one of these mineral items is stone and Iran is one of the countries that have a lot of mineral stones for buildings and decorations [8]. Iran has the highest second resources of decorative stones and has the highest first diversity of stones in the world. Non-metal mineral industry is also one the mineral materials and products having considerable benefits of production and export due to the huge mineral resources in the country. According to the added value owned by this industry, its development must be seriously included in planning and policy making $[3,4]$. Having many manufacturing benefits including raw materials, fuel, energy, human force and etc, this industry has become very important in recent years and has grown very much in the group of mineral materials and products. For this reason, the production of the most of the subgroups of this industry (production of tile and ceramics, stone, porcelain, crystal and glass, block joist, different types of bricks, cement, calcining limestone, producing different types of gypsum, aluminate concrete, dimensioning stone, stone synthetics, grading sands and producing micronized powder and stone powder) are economically justified. Some of the early problems of this industry are not having a specific export program and that it is not properly consumed [2]. On the other hand, according to the formal statistics published by customs office of Iran, the level of the export of this industry has declined. This decline is significant especially compared to the 1990s, when the industry had a high growth like other industries [10]. The problem that how it is possible to perform better than others at the same environment is a question noted by experts and various studies have been conducted on this issue [5]. As a result, according to what is mentioned, identifying these factors and fields are important for managers of organizations, because identifying them, in addition to allocating the resources optimally, the success of the organization will be also guaranteed in a competitive environment. So it is necessary to do such a research in Iran and in an industry whose macro-economical measures are noticeable. So the purpose of the research is to evaluate the effect of the elements of the resource-based approach on the export performance based on the focus strategy in non-metal mineral industry of the country. This model is tested based on the opinions of senior and top managers of the companies involved in the research. 


\section{History of the research}

For many years, researches that were conducted about export faced with a big lack [13]. Studies on export business are classified into three groups: 1. Stages of export development of companies [19], 2. Studies on the export attitudes of companies [24], and 3. Studies on the export performance $[3,5,11,12,13,21,22,23,24,25,26,27]$. This research emphasizes the export performance to improve the performance of the companies involved in the research. Past studies on the export performance have widely examined factors of the success of the export performance. For example, such studies examine the effect of features of company, characters of managers, external environment and marketing strategies on the export performance. However, in the studies above, no similar and consistent findings are obtained due to using different measures, different markets and distinct conceptual development. This study examines various views on the factors effective in the export performance based on theories and experiences of different business fields. Chetty (1993) states that in the literature of export performance, a theory is needed that can explain the changes in the export performance [18]. Although the past studies in the literature of export have largely offered a conceptual framework (Cavusgil\&Zou, 1994; Gang Turk\&Koutabe, 2001; Katsikeas, Pearsi and Leonidis, 1996), the process of making international (Har\& Ertis Bounafina, 1995; Wolf\&Pat, 2000; Yep, Biskari\&Monti, 2000), the paradigm of strategy-structure-performance (SSP) (Madson, 1987) and the relational paradigms (Stiles\&Ambler, 1994, 2000), marketing researchers did not pay enough attention to the originality of the researches (Seriostaff, Fahi\& Christain San, 2001) and the review of the related literature shows it. Very few researches have been conducted on this issue including those by Miros (1997), Pang\&York (2001) and Wolf\&Pat (2000) [12]. According to the importance of the subject, different researches are conducted about identifying factors effective in the export performance in different industries in different countries; in any of these researches, variables were chosen that according to the idea of the researcher, directly or indirectly affected on the export performance [15,23]. The number of the variables examined was somewhat high, so that they have even created contradictory conclusions, findings and ambiguities [11]. Most of the early researches on the export were conducted for identifying exporters from non-exporters [21]. It means that they largely considered the process by which a company became international. After that, researchers examined external factors effective in the export attitude such as the encouraging programs [27]. In the third stage, researchers examined factors related to the attitudes of companies, corresponding to export and its results. The fourth group of the researchers examined the factors effective in the export performance or success of companies [23]. For example, presenting a model, Kasikid et al. examined the effect of three factors including objective features of the company, variables related to the export perception (export experience and amount, motive of export, export problems and competitive advantages) and commitment to export (the distinct part of export, entering the foreign markets and the criteria of customer's selection, visiting export markets permanently, export planning and control) on the export performance of European countries [22]. White, Grifit and Rians also analyzed some methods of export performance measurement in service sector. Valas and Baker also presented a model for the variables effective in the export performance in Australia [12]. In this study, they divided the variables into two classes of intangible (tendency, skill, knowledge) variables and tangible (distribution, product, communication with customer, control, suppliers) variables. Tirkal and Ramezani examined the effect of competencies (Technology, market and export knowledge, quality), marketing tendency, features of the company, strategy and environment on the export performance of companies. In the model presented by them, features of the company affect on the export performance due to affecting on the strategy. Shoham and Crop (1998) examined the effect of the mixed marketing variables on the export performance [17]. 
The same year, reviewing the past studies, Zou and Sten also introduced a $2 * 2$ framework for classifying various factors effective in the export performance [24]. This framework classifies factors effective in the export performance into two classes of controllability and uncontrollability and the classes of inter-organizational and outer-organizational. Combining these classes, a box is obtained for classifying factors effective in the export performance. In 2000, Dil, Tomengoch and Paul Mayers examined the effect of the factors of company's features (company's size, barriers of entrance, and years of company's involvement in business), competency of the company (export experience) and export marketing strategies (focusing on the market against being diverse and being active against being passive) on the export performance of the company [18]. The same year, presenting a model, Baldauf, Cravens and Wagner examined the relation between environmental features (social, cultural, political), company's features (demography, motives of management), business strategies (distinction or the least finished price) and the export performance [13]. In 2002, classifying export companies into three groups including defenders, analysts, and seekers, Shoham et al. introduced various variables effective in the export performance in any of these companies [25]. In their research, they concluded that in analyst companies, there is a significant relationship between producing new product, management of production, tendency of the market, and control strategies on one hand, and the export performance on the other hand. The same year, Rose and Shoham examined the effect of having a market tendency by a company on its export profit and sale. In 2002, presenting a model, Kisikid et al. introduced the three variables of export attitude, export barriers and management's support as those effective in the export performance $[25,26]$. In addition to affecting directly on the management's support variable, the first two variables indirectly affected on the export performance. The same year, analyzing the previous researches, Leonidou, Katsikeas and Samiee presented a model, in which the effective variables were divided into five groups (characters of management, organizational factors, environmental pressures, export purpose setting and elements of export marketing strategy) [25]. Affecting on the next two variables, the first three variables directly affected on the export performance. Based on an extensive study conducted on domestic different resources, only four cases of research were observed about the export performance that are presented in the following. In his research, factors effective in the export performance of small and medium sized companies, Dehdashti (2007) evaluated the effect of three groups of factors (competencies of the company, features of the company, and export marketing strategy) as 33 sub-variables on the export performance for the development of the export objectives of small and medium sized companies, and the results showed that there was a positive effect and relationship between the factors above and the export performance [5]. DehYadegari (2004) examined the relationship between dimensions of competitive advantage and the export performance of Iranian companies exporting decorative stones. In this research, adopting the resource-based attitude and the aim of finding one of the main reasons for the low general level of export in the stone industry, the level of the effect of the dimensions of the competitive advantage (quality, efficiency, innovation, and responsiveness to customers) on the export performance is examined. Then, presenting a conceptual model, the relationship between the dimensions of the competitive advantage of the companies exporting decorative stones and their export performance were tested. The results of the research show that 1) although companies exporting decorative stones had a desirable quality level, they had a low level of other competitive advantages (efficiency, innovation and responsiveness to customers), and 2) there was a positive significant relation between the dimensions of the competitive advantage and the export performance of the companies exporting decorative stones [6]. In another research, Najafi-e-Majd (2008) identified factors determining the export performance in the food stuff industry [9]. In this study, the effect of ten factors including size of company, export experience, export stimulants, export problems, competitive advantages, export commitments, 
product adaptation strategy, price adaptation strategy, direct export channels and foreign advertisement costs on the competitive performance were examined to help to the development of export and export marketing in the field of food stuff industry. The results of the research showed that there were significant relationships between the ten factors and the export performance of these companies. Hosseini-e-touli (2010) examined the effect of export incentive programs on the export performance in electrical industry with an adoption from an external attitude to the field of export performance (occasional approach) and evaluated the effect of encouraging programs of the government on the export performance [3]. It must be mentioned that in this research, the variable of the competitive resources of the organization is composed of four variables including physical resources, human resources, technological resources and relational resources. The variable of competitive capabilities also addresses the capabilities of marketing, relational and organizational strategic researches. The variable of organizational systems addresses the way of organizing and the existence of efficient systems in any firm to increase the productivity. Following the identified principles, governance unity, assigning responsibility, monitoring and control, work division, coordination, personnel systems and management information system are the necessities for administrating any organization. The focus strategy addresses the level of the development of a new product, a special innovation in certain processes and the capability of building specific products for a certain group of customers, and finally, the export performance is the level that the strategic and economic aims of a company are fulfilled about exporting a product to a foreign market through planning and enforcing the export marketing strategy [17]. In this research, the measures including the export sales ratio, export growth, volume of export sales and the level of achieving the export strategic aims are used as the measures determining the export performance of companies.

\section{The conceptual model/ hypotheses of the research}

The research is to find that how the resources lead directly and indirectly (through distinction competitive strategy) to high levels of performance. The conceptual model of the present research combines indeed three main elements in the strategic management, i.e. the internal environment (resources, capabilities and the competitive organizational systems), distinction competitive strategy and the export performance. The model presents the relations between these three main elements. Based on the industrial organization (IO) theory, it is the structure of an industry that determines the behavior of a company and these factors determine the performance of a company. The external environment significantly affects on the strategy and the performance of a company [23]. But based on the resource-based approach, the internal competitive resources of an organization can be the origin of the competitive advantage and using these resources correctly and effectively improves the competitiveness of the organization $[14,26,27]$. So adapting the internal competitive resources to the external environment leads to the formulation of competitive strategies that brings about a desirable performance for the organization.

In some cases, the competitive resources will create a desirable performance directly, because companies are not able to identify these resources to develop competitive strategies. In other cases, the results of the performance make the managers aware that some resources may exist in the company that can develop the competitive strategies and in other cases, a desirable performance may be the result of a period of prosperity of an industry [25]. Therefore, it is necessary that companies analyze the results of various views and modify their strategies according to a certain plan $[19,16]$. The competitive resources of a company can affect on the performance and such these resources are almost in the control of the company. Based on the analysis of the competitive resources and the environment, the related strategies must be 
developed to apply the activities of the company. Competitive strategies are indeed a class of the strategies of an organization that can be adapted to the complex competitive environment. It is necessary that the companies get the desirable performance in the competitive performance such as the maximum profit to increase and improve the value of the stockholders. So it can be concluded that the performance is a very important measure for evaluating the effectiveness of a suitable competitive strategy [15]. The conceptual model presents a framework for executive managers and researchers to be able to understand the competitive strategy of the companies in a dynamic environment. The performance of a company depends on the identification and an accurate definition of the suitable competitive strategies and formulating such strategies is the result of the analysis of the environment and the competitive resources. In figure 1, the conceptual model of the research is presented. It must be mentioned that in this model, valid measures in the perspective of the resource-based approach are used to measure the export performance. This model is presented to complement the approach-strategy-performance paradigm by considering all of the elements and components of the resource-based approach.

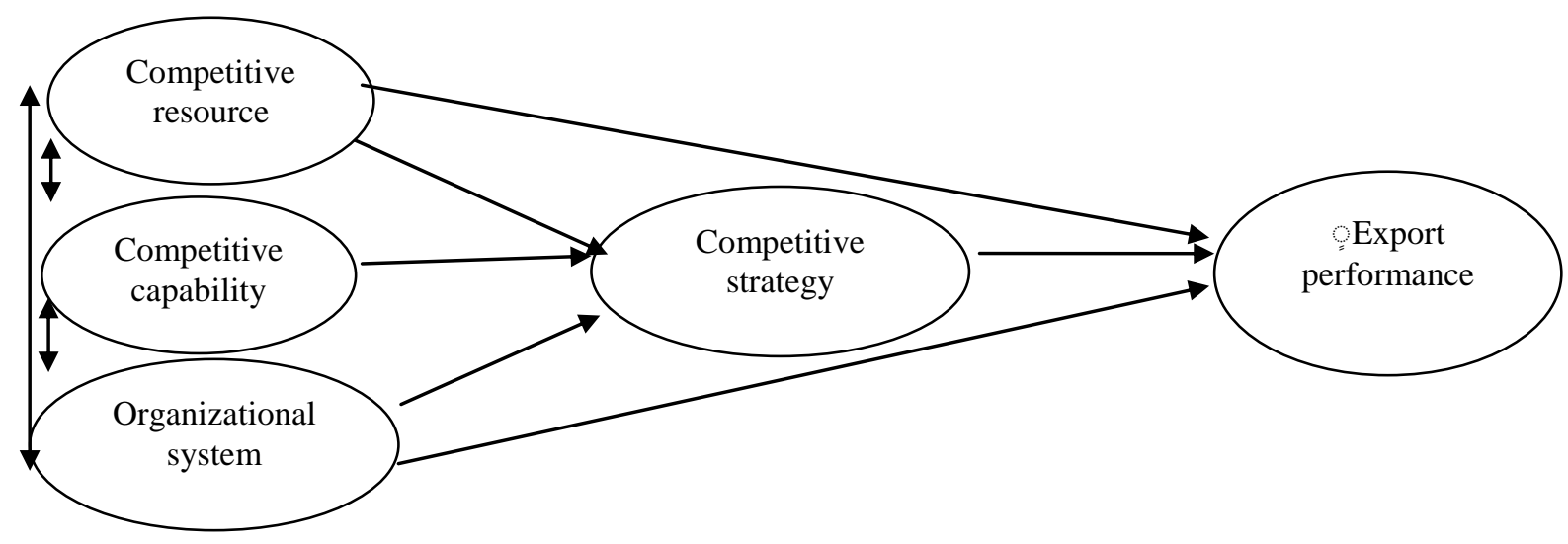

Figure1. The conceptual model of the research

In the conceptual model above, all of the relations between the concept, dimensions, components and measures [1] are defined as the measurement relations as simple and multiple regression models. In this conceptual model, the hypotheses of the research are defined as follows:

1. There is a significant relationship between resources and organizational capabilities.

2. There is a significant relationship between resources and organizational systems.

3. There is a significant relationship between capabilities and organizational systems.

4. Organizational resources significantly affect on the competitive strategy.

5. Organizational capabilities significantly affect on the competitive strategy.

6. Organizational systems significantly affect on the competitive strategy.

7. Competitive strategy significantly affect on the export performance.

8. Organizational resources significantly affect on the export performance.

9. Organizational capabilities significantly affect on the export performance.

10. Organizational systems significantly affect on the export performance.

In table 1, the main resources for extracting the hypotheses of the research are presented. 
Table 1. History of the hypotheses of the research

\begin{tabular}{|c|c|c|}
\hline Hypothesis & Relation of the variables & Researcher (year) \\
\hline 1 & Resources and capabilities & $\begin{array}{l}\text { Barney, 1991, 2001a, 2001b; Prime\&Batler, } \\
\text { 2001a, 2001b; Morgan et al., 2004; Ainodin et } \\
\text { al., 2007; King, 2007b; Sirmon et al., 2007; } \\
\text { Morgan et al., 2004; Prahalad and Hammel, } \\
\text { 1990; Grant, 1996; and Hunger and Wilen, } \\
\text { 2009 }\end{array}$ \\
\hline 2 & Resources and system & $\begin{array}{l}\text { Vernerfelt, 1984; Porter\&Milar, 1985; Barney, } \\
\text { 1991, 2001a, 2001b; Prime\& Batler, 2001a, } \\
\text { 2001b; Charbaghi\& Linch, 1999; } \\
\text { Miller\&Ross, 2003; Gimens\& Vantura, 2002; } \\
\text { Koulotla et al., 2003; Maskaran, H. et al., 1998; } \\
\text { Ma, 1998b; Wiklond\&Sheferd, } 2003\end{array}$ \\
\hline 3 & Capability and system & $\begin{array}{l}\text { Prahalad\&Hammel, 1990; Maskaran, H. et al., } \\
\text { 1998; Winter, 2003; Ray et al., 2004; Vas, } \\
\text { 2005; Pers-Faryajeh and Ankel, 2007; Koulota, } \\
\text { et al., 2003; }\end{array}$ \\
\hline $4,5,6$ & Resources and strategy & $\begin{array}{l}\text { Vernerfelt, 1984; Dirix and Koul, 1989; Ma, } \\
\text { 1999a, 1999b; Wiklond\&sheferd, 2003; } \\
\text { Morgan et al., 2004; Santa Paraj et al., 2006; } \\
\text { Fousavan\& Kanchana, 2007; Hitt, Birman, } \\
\text { Shimizou\& Couchhar, 2001 }\end{array}$ \\
\hline 7 & Strategy and performance & $\begin{array}{l}\text { Parnel\&Wright, 1993, Kim Man, 2010; } \\
\text { Kim\&Lim, 1988; Barney, 2002; Koutabeh, } \\
\text { Tigen\& Alach, 2000; Ma, 2000; Fahi, 2000; } \\
\text { Wang\&Lou, 2003; Wiklond\&Sheferd, 2003; } \\
\text { Mirgan et al., 2004; Franco-Santoz et al., 2007 }\end{array}$ \\
\hline $8,9,10$ & $\begin{array}{l}\text { Elements of the } \\
\text { resource-based approach } \\
\text { (resources, capabilities and } \\
\text { system) and performance }\end{array}$ & $\begin{array}{l}\text { Barney, 1991; Fahi, 2000; Gimens\&Vantura, } \\
\text { 2002; Wiklond\&Sheferd, 2003; } \\
\text { Bovan\&Esterof, 2004; Morgan et al., 2004; } \\
\text { Sirmon et al., Cooper\& Klin Smidth, } \\
\text { Moeini, 1985; Wagner, 1995\&2007. }\end{array}$ \\
\hline
\end{tabular}

\section{Methodology of the research}

\subsection{Research's design}

The present research is an applied-development one according to the purpose; it is an applied one, because such these researches are directed toward the practical application of the knowledge and the results to solve the problems and since it is to discover the facts and recognize the phenomena and develops the general boundaries of knowledge, it is a development research [1:79]. It is a descriptive research in terms of collecting data and is a descriptive, analytical, and correlation research of the type of structural equations. The descriptive research includes collecting data for testing hypotheses or answering the questions related to the current circumstance of the subject being studied. The descriptive data are usually collected by questionnaires, interviews or observation and can't be manipulated and the research is a passive one (what the study is) in this aspect (the extent of the intervention of the researcher in the research). In the correlation research, the main aim is to find that whether there is a relationship between two or some quantitative (measureable) variables and if there is a relation, how much it is. The aim of the correlation study may be the establishment of a 
relation or removing it and using the relations for predictions. The correlation studies evaluate the variables that are thought to be related to the problem [1:200]. The research is a quantitative one in terms of the data type (measurement), because data are as numbers and values and are drawn by questionnaire and it has a quantitative method for data analysis. It is a descriptive one in terms of the approach, nature of the problem and the purpose, because it is to describe factors effective in the export performance [1:189]. Finally, the research uses the theory testing method in terms of dealing with theories. While testing any theory, we use the theory in order that our observations are directed. Here, we move from the generic to the specific and the observations must be a test determining the theory. Describing the relations between the variables, this research is to develop the knowledge existing about the practical principles and rules of the subject being studied and in this research, using the path analysis, factors effective in the export performance of non-metal mineral industry are evaluated.

\subsection{Tool of data collection}

In this research, the library studies method is used to collect the secondary data that includes reviewing foreign management magazines, internet sites for management, database of foreign theses, documents and reports of organizations and public and private institutions, and also reports and documents of the companies exporting non-metal mineral industry. Interviews (30 samples) and questionnaires (52 questions) were also used for collecting primary data. Interview is also used for drawing factors of the components of the research.

\subsection{Validity and reliability of the research}

In this research, the validity of the questionnaire was obtained using two content and factorial validities. The content validity of this questionnaire was examined by the supervisors and the advisors and 5 faculty members of universities and also 10 experts of non-metal mineral industry and the required modifications were applied on the questionnaire. In this research, the factorial validity (exploratory factor analysis) was used for determining the validity of the component. Also, Cronbach's Alpha method was used for determining the reliability of the measurement tool. The reliability factor is defined in a domain from 0 (non-reliability) to 1 (full reliability) [3:75]. For this purpose, according to the final sample that includes 91 questionnaires from companies exporting the intended industry, the questionnaires were collected and then, using the data obtained and the SPSS Software, the reliability factor was calculated using Cronbach's Alpha method that is presented in table 2.

Table 2. Results of Cronbach's Alpha test

\begin{tabular}{|c|c|c|}
\hline $\begin{array}{l}\text { Component } \quad \text { (latent } \\
\text { variable) }\end{array}$ & $\begin{array}{l}\text { Alpha's } \\
\text { value }\end{array}$ & Resource \\
\hline Competitive resources & 0.892 & $\begin{array}{l}\text { Barney,2001\&1991; Michalisin et al., } \\
\text { 1997; Pank and York, 2001; } \\
\text { Kamlou-Ardaz, et al., } 2003\end{array}$ \\
\hline Competitive capabilities & 0.949 & $\begin{array}{l}\text { Anderson\&Kim, 1998; Guilen, 2000; } \\
\text { Hall, 1993; Michalisin et al., } 1997\end{array}$ \\
\hline Organizational systems & 0.833 & $\begin{array}{l}\text { Nelson\& Winter, 1982; Porter, 1991; } \\
\text { Farjon, 1998; Stike et al., } 1992\end{array}$ \\
\hline $\begin{array}{l}\text { Distinction competitive } \\
\text { strategy }\end{array}$ & 0.896 & Hashem, 2000; Porter, 1980 \\
\hline Export performance & 0.881 & $\begin{array}{l}\text { Leonidou et al., 2002; Varval\&Dun } \\
\text { Krez, 2002; Wolf\&Pat, } 2000\end{array}$ \\
\hline
\end{tabular}


The values calculated for the reliability factor of every variable of this pretest (all of the calculated values are higher than 0.7 ) show that the questionnaire has the required reliability to be distributed among the population.

\subsection{Method of data analysis}

The first and second order confirmatory factor analysis and the path analysis were used for testing the hypotheses. Data analysis was also conducted by LISREL8.53 and SPSS software.

\subsection{The population, sample size and the sampling method}

The population of the research includes all of the companies exporting non-metal mineral industry in Tehran that came to the central office in the time interval of the research. In this research, the shared random classified sampling method was used in two stages. In the first stage, the list of the export companies was provided in 11 groups of the intended industry and then, the contribution of any group was determined for doing the research. In the second stage and after determining the contribution of any group, a number of them were randomly chosen and the questionnaires were filled by them. The number of the companies exporting this industry actively were 1142 (ministry of industry and mines) and based on it, the sample size was estimated equal to 300 companies based on Morgan's table at the level of error 5\% and the accuracy 0.1 .

\section{Analysis of the data of the research}

The descriptive analysis of the demographic variables of the research was conducted in two individual (5questions) and company (4 questions) sections. In this study, in the section of personal characteristics, $81.8 \%$ of the respondents were male and $18.2 \%$ of them were female, and most of the respondents $(84.6 \%)$ had the first or higher academic degree. Respondents with the first academic degree had also the highest frequency $(52.3 \%)$ among the respondents. The results obtained from the research about the job experience of people show that $16.8 \%$ of the respondents had less than 5 years of job experience, $18.6 \%$ had job experiences for 5 to 10 years and $28.8 \%$ had also more than 15 years of job experience. The organizational position of most of the respondents of this research was export manager $(37.9 \%)$. The highest age frequency of the respondents $(56.8 \%)$ was more than 45 years old. In the section of the features of the companies being examined, most of the companies involved in the research $(38.9 \%)$ had more than 15 years experience in international marketing and export and it shows that most of the companies being examined had enough experience in export. Also, 33.7\% of the companies had from 10 to 15 target markets in the intended industry and after it, $31.9 \%$ of the companies also exported to 1 to 5 countries. Finally, the export method of having an agency or distributor outside of the country had the highest usage (26.7\%) and the export method of having an export management company had the lowest usage (1.4\%) among the companies. In addition, the level of data analysis was industry and the level of data collection was company.

The test of the relations between the latent and observable variables was conducted by LISREL8.53 software. The results of the first and second order factor analysis based on the distinction competitive strategy shows that according to the competitive resources (RES), the physical resources $(92 \%)$, the technological resources $(88 \%)$, the relational resources $(84 \%)$ and the human resources $(65 \%)$ had respectively the highest percents explained in the dimension of resources. also, the results of the first and second order factor analysis show that according to competitive capabilities (CAP), the strategic capabilities (87\%), the relational capabilities (86\%) and the marketing research capabilities (84\%) had respectively the highest percents explained in the dimension of capability. In the dimension of organizational systems (SYS), the organizational knowledge had the highest percent explained with $84 \%$ in the dimension of resources. The Latin expressions FOCUS and EXPORT also mean focus strategy 
and export performance, respectively. In the following and in figures 2 and 3, the models of the research are presented in two standard estimation and significance states. Figure 2 shows the structural model of the research in the state of standard estimation based on the focus strategy. In this figure, the fit indices of the model are presented that are described as follows:

1. The calculated $\chi^{2}$ value is equal to 241.82 and the df value is 125 and hence, the value of $\chi^{2} / d f$ is less than 3 and it shows that the structural model of the research is suitable.

2. The RMSEA measure is 0.078 that is less than 0.08 . it also shows that the structural model of the research is suitable.

3. The NFI measure is 0.96 , the GFI measure is 0.97 and the AGFI measure is also 0.89 and all of them show that the structural model of the research is suitable.

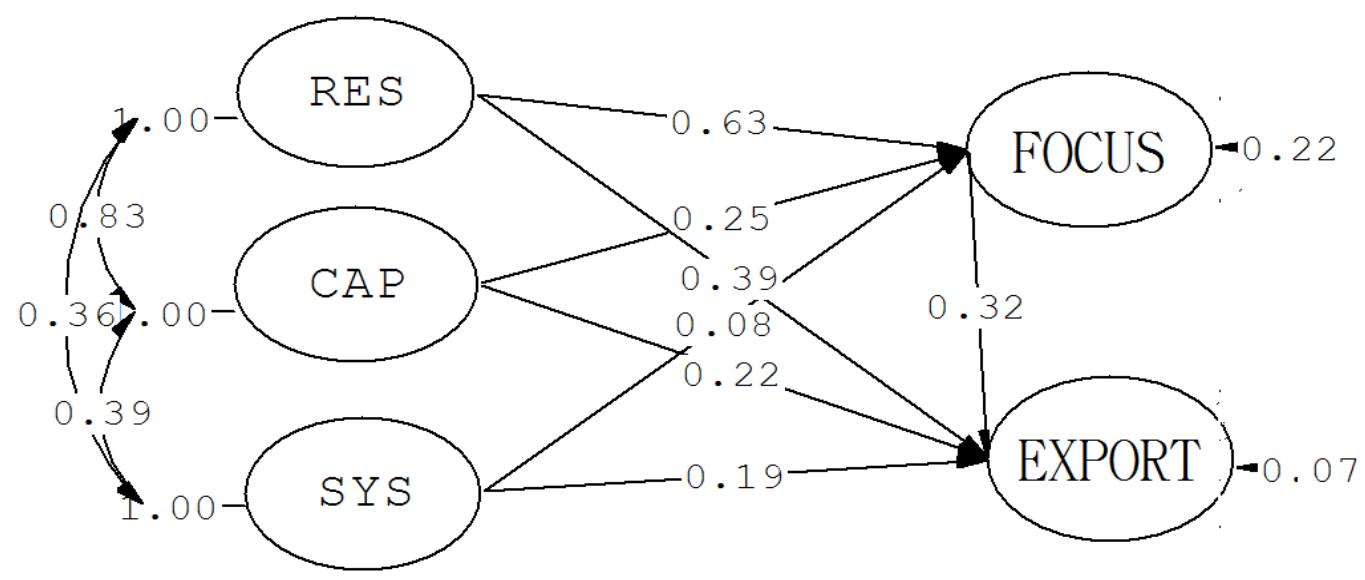

Chi-Square $=241.82, \mathrm{df}=125, \mathrm{P}-$ value $=0.00000, \mathrm{RMSEA}=0.078$

Figure 2. The structural model (path analysis) of the research in the state of standard estimation

Figure 3 shows the significance level (t-value) of the coefficients and the parameters obtained from the structural model of the research and all of the coefficients obtained are significant, because the values of the significance test (t-values) of all of them are highest than 1.96. The significance of these values shows that the model is significant. In other words, putting any measures and variables in a general model is significant.

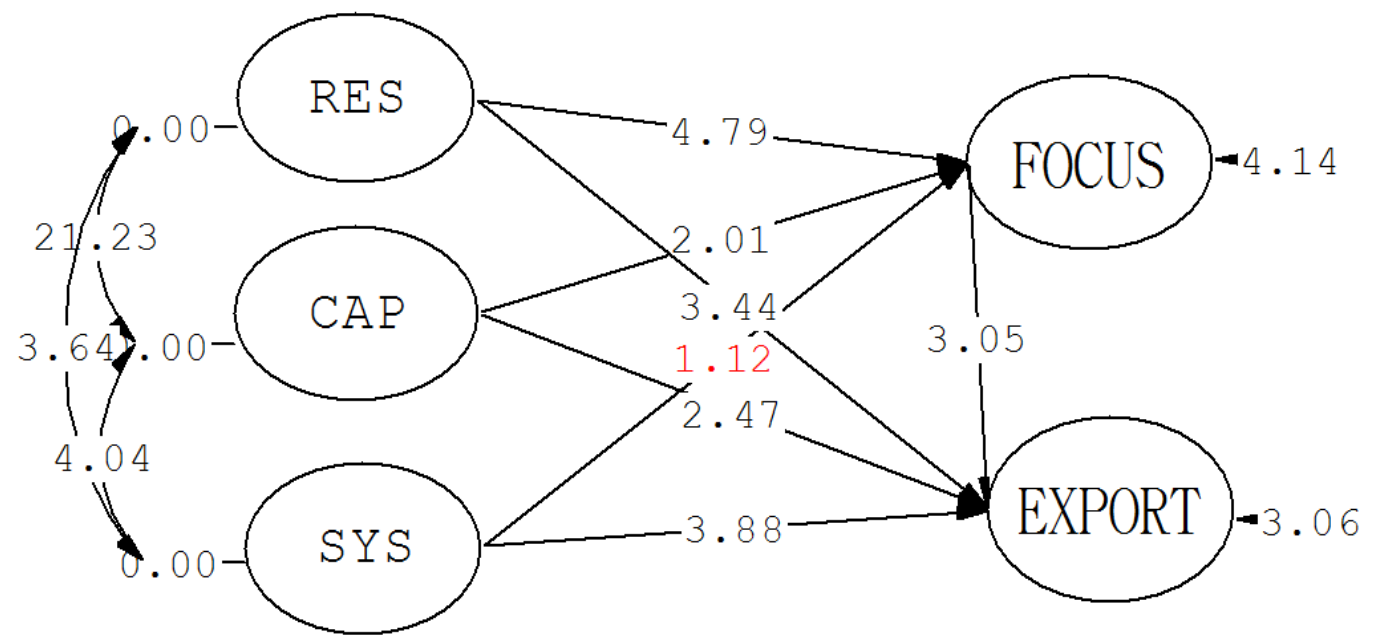

Chi-Square $=241.82, \mathrm{df}=125, \mathrm{P}-$ value $=0.00000$, RMSEA=0. 078

Figure 3. The structural model (path analysis) in the state of significance coefficients 
The results of the path analysis in figure 2 show that using the focus strategy, the dimension of the competitive resources has a contribution and a weight higher than the dimension of the competitive resources and organizational systems to form the distinction strategy, so that the level of the effect of the competitive resources on the distinction strategy is $65 \%$ and it is $25 \%$ and $8 \%$ respectively for competitive capabilities and organizational systems. According to the effect of the elements of the resource-based approach on the export performance and based on the intended (focus) strategy, the level of the effect of the competitive resources on the export performance is $39 \%$ and it is $22 \%$ and $19 \%$ respectively for competitive capabilities and organizational systems. The management result of this discussion is that using the focus strategy, the competitive resources have the highest effect on the formation of the company's strategy and the export performance of the companies active in the international markets. So those using this strategy must invest more in the competitive resources, especially the physical and the technological resources. Figure 3 that shows the path analysis model in the state of the significance coefficients also shows that all of the relations defined in the hypotheses are significant and all of the hypotheses are supported. Also, in table 3, the direct and the indirect effects between the variables of the research are discussed.

Table 3. Results of the direct, indirect and total effects of the variables of the research in the distinction strategy

\begin{tabular}{|l|l|l|l|}
\hline Variables & Direct effect & Indirect effect & Total effect \\
\hline $\begin{array}{l}\text { The effect of competitive resources on } \\
\text { distinction strategy }\end{array}$ & 0.63 & - & 0.63 \\
\hline $\begin{array}{l}\text { The effect of competitive capabilities } \\
\text { on distinction strategy }\end{array}$ & 0.25 & - & 0.25 \\
\hline $\begin{array}{l}\text { The effect of organizational systems } \\
\text { on distinction strategy }\end{array}$ & 0.08 & - & 0.08 \\
\hline $\begin{array}{l}\text { The effect of distinction strategy on } \\
\text { export performance }\end{array}$ & 0.32 & - & 0.32 \\
\hline $\begin{array}{l}\text { The effect of competitive resources on } \\
\text { export performance }\end{array}$ & 0.39 & 0.20 & 0.59 \\
\hline $\begin{array}{l}\text { The effect of competitive capabilities } \\
\text { on export performance }\end{array}$ & 0.22 & 0.08 & 0.30 \\
\hline $\begin{array}{l}\text { The effect of organizational systems } \\
\text { on export performance }\end{array}$ & 0.19 & 0.02 & 0.21 \\
\hline
\end{tabular}

This table shows that using the competitive distinction strategy, the effects of competitive resources, competitive capabilities and organizational systems on the export performance are increased. This conclusion is drawn by comparing the direct effect column and the total effect column.

\section{Discussion and conclusions}

The purpose of doing this study was to present a model for evaluating the effect of the elements of the resource-based approach on the export performance based on the distinction strategy in the non-metal mineral industry of the country. Reviewing the research literature on the export performance, it can be found that it is the first study that has examined the relation between the elements of the resource-based approach and the export performance based on the competitive focus strategy and has presented a conceptual model for measuring it. The results show that the competitive resources are more important than other elements of the resource-based approach (competitive capabilities and organizational systems) for formulating the strategy and determining the export performance of the chosen companies. In addition, the dimension of the physical resources has more weight than other dimensions (technological resources, human 
resources and relational resources) to form the concept of the competitive resources. The results of the research are consistent with those of other researches. Studies have shown that there is a positive significant relationship between the resources and the organizational capabilities [23, 24, 17, 15, 5]. Also, the findings of other researches have concluded that the resources and the competitive capabilities are significantly related [11, 17, 14, 24, 23, 22]. Parahald and Hammel (1990), Grant (1996) and Hunger and Wilen (2009) have also modeled the existence of a positive significant relationship between the resources and the organizational capabilities [24]. Studies have shown that there is a significant relation between the systems and the organizational resources [22,24]. The empirical results of other researches state that the organizational resources significantly explain the difference in the organizational systems [19, $12,13,17,23]$. Other research has also proposed the conceptual theory that there is a significant relationship between the systems and the organizational resources, especially to improve the performance of a company $[18,12,14,11]$. In the researches above, the type of the strategy is not mentioned. The review of the studies shows that there is a significant relationship between the systems and the organizational capabilities [164: 6,22, 25, 26, 27, 24, 14]. Findings of other studies also support the existence of a significant relationship between systems and the organizational capabilities [11,13]. The effectiveness of the organizational capabilities is improved using the desirable organizational systems properly. Also, the studies by Leonidou et al. (2002), Hosseini-e-touli (2010) and Ibeh and Wheeler (2005) support the existence of a significant relationship between the focus strategy and the performance $[21,3,26]$. On the other hand, researches by Kim Man and Azizi (2009), Kaleka et al. (2002), Kim Man (2010), Dhanaraj and Beamish (2003) and Bani-Hani and AlHawary (2009) show the existence of a positive significant relationship between the elements of the resource-based approach (competitive capabilities and resources) and the distinction strategy, that is consistent with the results of the present research [19, 12, 25, 24, 23]. Cavusgil and Zou (1994), Baldauf and Croner (2000) and Chetty and Hamilton (1993) have also concluded that the elements of the resource-based approach (strategic capabilities and resources of an organization) highly affect on the performance of the companies active in a special industry $[13,17,18]$. Comparing the results of the research with past researches, it can be concluded that they are consistent with most of the past studies.

Scientifically, in addition to time and financial limitations, the method of data collection is also one of the other limitations of the research. Unfortunately, due to the absence of a database related to the variables of the research in the companies being examined, data were collected by questionnaires, except for the performance data that were obtained by the customs office and the ministry of industry and mines of the country. Although it was tried very much to standardize the questionnaire, it is biased by the respondents and if the respondents give distorted information, the researcher has no objective criteria to evaluate the answers received. So the practice that the researcher can apply to measure the validity of the results is to repeat it in other industries and compare the results. Theoretically and according to the marketing science, the important and key variables effective in the performance of companies include variables of the community, customers and company that are known as $3 \mathrm{C}$ variables. One of the limitations of the research is to examine a set of factors (at the level of company) and other factors are not examined in this research. On the other hand, in addition to affecting on the financial performance, the elements of the resource-based approach are also effective in the non-financial performance of a company (such as satisfaction, commitment, loyalty of the employees and customers). But in this research, other factors are not examined. One of the other limitations of the research is that other approaches are not involved in the model of the research including the occasional and the relational approaches, that can give more real results than the resource-based approach to explain the changes of the export performance of the companies of the intended industry. 
According to the results of the present research, the following suggestions are necessary for future researches:

1. Doing research in the companies of the non-metal mineral industry as specialized subgroups;

2. Doing research with the same approach in other industries of the country;

3. Examining the way that the elements of the model affect on each other;

4. Examining the effect of other approaches (occasional and relational approaches) and comparing their results with those of the resource-based approach in this industry;

5. Identifying the effect of the elements of the resource-based approach on the non-financial performance at the macrolevel of a company such as satisfaction, commitment, loyalty of the employees and customers of the company;

6. Comparing the export performance of the non-metal mineral industry with the same industry in the competitor countries;

Comparing the export performance of non-metal mineral industry with other domestic industries.

\section{References}

1. Bazargan, A., Sarmad, Z., \& Hejazi, E., method of research in behavioral sciences, Agah Pub., Tehran, 2004

2. Bidabad, B., intersection communications and setting the purpose of increasing occupation in the country, agricultural economy and development magazine, $12^{\text {th }}$ year, no. 46, Tehran, 2004.

3. Hosseni-e-touli, F., examination of the effect of export incentive programs on the export performance of electrical industry, phD. thesis, guided by Hasangholipour, T., Tehran University, 2010.

4. Productive cooperation office, ministry of cooperatives, an analysis of the status of cooperative non-metal mineral companies and machinery producing and casting, ministry of cooperatives, Tehran, 2008.

5. Dehjdashti Shahrokh, Z., factors effective in the export performance of small and medium sized companies, journal of management studies, no. 53, 2007.

6. DehYadegari, S., examination ,of the relationship between dimensions of competitive advantage and the export performance of Iranian companies exporting decorative stones, bulletin of business, 2004.

7. Fahimifar, J., the global market of decorative stones and the export share of Iran, $1^{\text {st }}$ ed., institute of business studies and research, Tehran, 1997.

8. Ghorbani, M., an introduction to economical geology of Iran, organization of geology and mineral discoveries of Iran, $1^{\text {st }}$ ed., Tehran, 2002.

9. Najafi-e-Majd, S., identifying factors determining the export performance in food stuff industry, MA dissertation, guided by Dr. Haghighi, M., Tehran University, 2008.

10. Nahavandian, M., horizons and lessons in business policy making, company of business publications, $1^{\text {st }}$ ed., 2001.

11. Aaby, Nils-Erik, and Stanley F. Slater. 1989. "Management influences on export performance: A review of the empirical literature 1978-1988." International Marketing Review 6(4):7-26.

12. Bani-Hani J. \& AlHawary F.(2009)The Impact of Core Competencies on Competitive Advantage: Strategic Challenge. International Bulletin of Business Administration. Issue 6 ,PP.93-104.

13. Baldauf, A., Cravens, D. W., \& Wagner, U. 2000. Examining determinants of export performance in small open economies. Journal of World Business, 35(1): 61-79. 


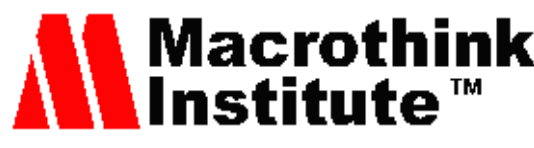

14. Barney, J. (1996). Gaining and sustaining competitive advantage. Reading, MA: Addison-Wesley Publishing Company.

15. Barney, J. (2001): "Is the Resource-based View a useful perspective for Strategic Management research? Yes", Academy of Management Review, vol. 26, pp. 41-56.

16. Cadogan, J., Cui, C., \& Li, E. (2003). Export market-oriented behavior and export performance: the moderating roles of competitive intensity and technological turbulence. International Marketing Review, 20(5), 493-513.

17. Cavusgil, S. T., \& Zou, S. (1994). Marketing strategy-performance relationship: an investigation of the empirical link in export market ventures. Journal of Marketing, $8,1-21$.

18. Chetty, S. K., \& Hamilton, R. T. (1993). Firm-level determinants of export performance: a meta analysis. International Marketing Review, 10(3), 26-34.

19. Dhanaraj, C.\&Beamish, P.W. 2003.A resource-based approach to the study of export performance. Journal of small Business Management, 41(3): 22-61

20. Grant, R. (1999): "Contemporary Strategy Analysis. Concepts, Techniques, Applications", Blackwell publishers, Cambridge.

21. Ibeh K.I., \& Wheeler C.(2005). AResource-Centred Interpretation of Export Performance. International Entrepreneurship and Management Journal 1,PP. 539-556.

22. Katsikeas, C., Leonidou, L., \& Morgan, N. (2000). Firm-level export performance assessment: review, evaluation and development. Journal of the Academy of Marketing Science, 28(4), 493-511.

23. Kim M \& Azizi W.(2009). The Relationship Between Innovativeness, Strategy Types, Environment and the Export Performance of Small and Mediumsize Enterprises (SMEs) of Malaysian Manufacturing Sector. The Business Review, Cambridge * Vol. 13 * Num. 2.PP.145-154.

24. Kim Man M.M.(2010).The Relationship between Distinctive Capabilities, Innovativeness, Strategy Types and the Export Performance of Small and Medium-Size Enterprises (SMEs) of Malaysian Manufacturing Sector. International Journal of Management and Innovation, Volume 2, Issue1.PP.15-30.

25. Kaleka, A. 2002. Resources and capabilities driving competitive advantage in export markets: Guidelines for industrial exporters. Industrial Marketing Management, 31: 273-284.

26. Leonidou L.C., Katsikeas, C.S. \& Samiee, S. 2002. Marketing strategy determinants of export performance: A meta-analysis. Journal of Business Research, 55(1): 51-67.

27. Zou, S., Fang, E., \& Zhao, S. (2003). The effect of export marketing capabilities on export performance: an investigation of Chinese exporters. Journal of International Marketing, 11(4), 32-55. 